\title{
Methodology and results of comparative atmospheric tests of experimental conservation composition
}

\author{
Alexey E. Shlykov ${ }^{1}$, Evgeniy B. Mironov ${ }^{1}$, Sergey M. Gaidar ${ }^{2}$, Maxim P. Erzamaev ${ }^{3, *}$, and Leyla S. Kurmanova ${ }^{4}$ \\ ${ }^{1}$ Nizhny Novgorod State University of Engineering and Economics, 606340 Knyaginino, Russia \\ ${ }^{2}$ Russian State Agrarian University, 127550 Moscow, Russia \\ ${ }^{3}$ Samara State Agrarian University, 446442 Kinel, Samara region, Russia \\ ${ }^{4}$ Samara State Transport University, 443066 Samara, Russia
}

\begin{abstract}
The article presents the results of full-scale comparative tests of various protective compositions, for which the Movil car preservative, Litol-24 grease, PVC grease, K-17 preservation oil, experimental preservation compound (EKS-1) were used. The objects of conservation are steel plates of grades U8, 65G, 45, 40X, and St3. After the tests, etching, weighing, measuring the surface roughness of the samples were performed, and metal losses were determined. Tests of EKS-1 show protective efficacy comparable to that of greases, and in some cases, it significantly exceeds it. It is proved that the area of corrosion and metal loss during the test of the composition on these materials was not more than $4.7 \%$ and $5.3 \mathrm{~g} / \mathrm{m}^{2}$ per year, respectively. The research results show that the use of the protective composition EKS-1, due to its manufacturability, significantly reduces the complexity of work during the conservation of agricultural machinery, as well as ensures the protection of metal products during both short-term and long-term storage.
\end{abstract}

\section{Introduction}

Environmental exposure has an aggressive effect on agricultural machinery during storage, and electrochemical corrosion begins to develop on its surfaces. Corrosion processes reduce fatigue strength, provoke the formation of microcracks, which can subsequently lead to a loss of working capacity by the technique. There are many technical solutions to protect equipment from corrosion. The most common solution is to use protective coatings. The addition of corrosion inhibitors can significantly improve the effectiveness of protective coatings.

During the operation of agricultural machinery, as well as during storage, it is affected by various aggressive environments. In particular, aggressive media include the juice of plant residues of transported goods, mineral or organic fertilizers, precipitation, and much more. These substances reduce the durability of the paint film, which leads to the development of corrosion processes on the surfaces of parts of the working bodies of machines.

The situation also becomes aggravated by the presence in the design of machines of such compounds in which corrosion processes can proceed most actively: welded, threaded, butt, and other types of machines. The corrosion process in these areas provokes the formation of microcracks, which leads to the destruction of the joints and, as a consequence, the loss of machine performance $[1,2]$.
The presence of moisture on the working bodies surfaces of machines also leads to the development of corrosion processes. In this case, a moisture film on the surface equipment, which formed in the process of dew or precipitation, absorbs various contaminants and gases from the atmosphere of the surrounding air. As a result, a moisture film on the surface of the technique acquires the properties of an electrolyte, and corrosion processes begin to develop under it. Besides, the chemical heterogeneity of the metal also affects its carozine processes [1].

All of the above leads to huge irreversible metal losses, which globally annually exceed 2.5 trillion dollars. The fight against metal corrosion in developed countries is an expense equal to $4 \%$ of GDP [3].

Thus, an important task from a scientific and practical point of view is the development of highly effective means of corrosion protection, as well as technical means for their preparation and application.

Many modern technologies ensure high safety of agricultural machinery from corrosion during storage. Such technologies include the use of individual sealed shelters [4], protective heat shields [5], the use of tread protection based on compositions containing zinc powder [6], the improvement of washing and cleaning of parts in preparation for storage [7] and other technical solutions $[8,9]$.

At the same time, the development of anti-corrosion compounds that are capable of forming resistant protective films on the surfaces of metal parts is a

* Corresponding author: erzamaev_mp@mail.ru 
priority in the research of domestic and foreign scientists [10-12].

One of the ways to protect agricultural machinery from corrosion is the use of bitumen and fuel oil compositions. Improving the protective properties of agricultural machinery is due to the addition of the corrosion inhibitor Emulgin [13]. Improving the protective properties of fuel oil compositions occurs due to the introduction of $\mathrm{KO}-\mathrm{SGK}$ and cannon fat into the composition [14, 15]. These compositions are characterized by high adhesion to metal and excellent anti-corrosion properties.

There are developments to improve the anticorrosion properties of used oils, which often cover the working damage of agricultural machinery [16]. Inhibitors Mobiin-3, Emulgin, POOM significantly increase the protective properties of agricultural machinery [17].

The task of protecting the building structures of livestock buildings has led a team of domestic scientists to develop a volatile inhibitor of the IFKHAN series. The IFKHAN series volatile inhibitor effectively prevents corrosion of low-carbon steels operating in an atmosphere with high humidity and saturated with aggressive gases [18, 19].

The developer team focused on the task of creating environmentally-friendly and natural corrosion inhibitors. This task is associated with the research of scientists from around the world [20]. In particular, the authors presented are interested in successful studies to determine the protective ability of inhibitors obtained from plant materials of natural origin [21-23], as well as their mixtures [24].

Besides, work continues improving coatings based on polymers [25, 26] and epoxies, by replacing zinc chromates with more non-toxic zinc phosphate [27] in the latter or by adding graphene oxides [28].

There is a description of "smart" anticorrosion coatings [29]. "Smart" anti-corrosion coatings are obtained by enclosing corrosion inhibitors in so-called nanocontainers. This technology makes it possible to achieve its more efficient and economical use.

The analysis of the above literature sources shows that the use of corrosion inhibitors both separately and as part of complex compositions significantly enhances the protective ability of anticorrosion compounds, which encourages scientists to search for cheaper and more affordable components for their manufacture [30, 31].

\section{Materials and methods}

Atmospheric tests based on Open Joint-Stock Company «Plodopitomnik» Lyskovsky district of the Nizhny Novgorod region were associated with several tasks:

- verification of the protective properties of the experimental preservation composition made based on the developed inhibitor [32],

- comparing it with the most common preservative formulations used for treation surfaces stored in open areas.
The studied samples are the metals most often used in the manufacture of working bodies and other parts of agricultural machinery, such as steel U8, 65G, 45, 40X, and St 3 . The characteristics of the samples were determined before testing (Table 1).

Pre-weighed and polished to a roughness of $\mathrm{Ra} 0.63$, plates of size $150 \times 100$ were processed with the following compositions:

- Auto preservative "Movil" TU 2384-14804001396-2006;

- Litol-24 greasing GOST 21150-87;

- Preservative "Cannon Lard" TU 0254-00315301184-2004;

- Preservation oil K-17 GOST 10877-76;

- Experimental preservation composition EKS-1 (17\% inhibitor in vegetable sunflower oil).

Table 1. Weight and area of test specimens

\begin{tabular}{|c|c|c|c|c|c|c|}
\hline \multirow{2}{*}{$\begin{array}{c}\text { Compositio } \\
\mathrm{n}\end{array}$} & \multirow{2}{*}{$\begin{array}{l}\text { The total } \\
\text { area of } \\
\text { the } \\
\text { processe } \\
\mathrm{d} \\
\text { samples, } \\
\mathrm{m}^{2}\end{array}$} & \multicolumn{5}{|c|}{ The mass of the processed samples, g } \\
\hline & & U8 & $65 \mathrm{G}$ & 45 & St3 & $40 \mathrm{H}$ \\
\hline Movil & 0.0753 & $\begin{array}{c}394.1 \\
8\end{array}$ & $\begin{array}{c}272.4 \\
6\end{array}$ & $\begin{array}{c}487.3 \\
8\end{array}$ & 457.8 & $\begin{array}{c}471.1 \\
7\end{array}$ \\
\hline К-17 & 0.0752 & $\begin{array}{c}416.3 \\
9 \\
\end{array}$ & $\begin{array}{c}282.0 \\
6 \\
\end{array}$ & $\begin{array}{c}491.8 \\
7 \\
\end{array}$ & $\begin{array}{c}460.8 \\
5 \\
\end{array}$ & $\begin{array}{c}462.9 \\
2 \\
\end{array}$ \\
\hline $\begin{array}{l}\text { Cannon } \\
\text { Lard } \\
\end{array}$ & 0.0751 & $\begin{array}{c}276.6 \\
7 \\
\end{array}$ & $\begin{array}{c}393.2 \\
5 \\
\end{array}$ & $\begin{array}{c}430.1 \\
8 \\
\end{array}$ & $\begin{array}{c}456.6 \\
9 \\
\end{array}$ & $\begin{array}{c}463.8 \\
3 \\
\end{array}$ \\
\hline Litol 24 & 0.0754 & $\begin{array}{c}420.2 \\
8 \\
\end{array}$ & $\begin{array}{c}280.5 \\
1 \\
\end{array}$ & $\begin{array}{c}491.3 \\
1 \\
\end{array}$ & $\begin{array}{c}187.0 \\
5 \\
\end{array}$ & $\begin{array}{c}429.2 \\
6 \\
\end{array}$ \\
\hline EKS-1 & 0.0752 & $\begin{array}{c}411.8 \\
8\end{array}$ & $\begin{array}{c}305.2 \\
6\end{array}$ & $\begin{array}{c}498.0 \\
8\end{array}$ & $\begin{array}{c}456.5 \\
7\end{array}$ & $\begin{array}{c}474.5 \\
9\end{array}$ \\
\hline
\end{tabular}

For weathering tests, samples treated with protective compounds were fixed at an angle of $45^{\circ}$ on a corrosion stand located in an open area (Fig. 1). Tests of all processed samples were carried out continuously, starting from November 2018 for 12 months.

A layer of a protective coating was removed from the surface of the samples by dipping into a solvent (gasoline of the brand Regulator-92 (AI-92)) to determine the corrosion losses and the area of metal damage. Then the samples were weighed. A grid with a mesh size of $5 \times 5 \mathrm{~mm}$ was superimposed on the samples, and the area of corrosion lesions and darkening of the surface were calculated. The foci of corrosion smaller than $3 \mathrm{~mm}^{2}$ were considered individually for each plate.

Then, corrosion products were removed from the surface of the samples by etching in a solution of $\mathrm{NaCl}$ $(30 \mathrm{~g})+\mathrm{H}_{2} \mathrm{SO}_{4}(200 \mathrm{~g})$ per liter of distilled water at a temperature of $23^{\circ} \mathrm{C}$ for 60 minutes (Fig. 2). The samples were washed with water, treated with acetone, and weighed on a laboratory balance VLKT-500-M.

The change in roughness from the initial $\mathrm{Ra} 0.63$ was determined using the model 170622 profilometer (Fig. 3). The measurements were carried out separately for each sample by measuring five times along two axes 
of the same plane at arbitrary points and averaging the obtained values.

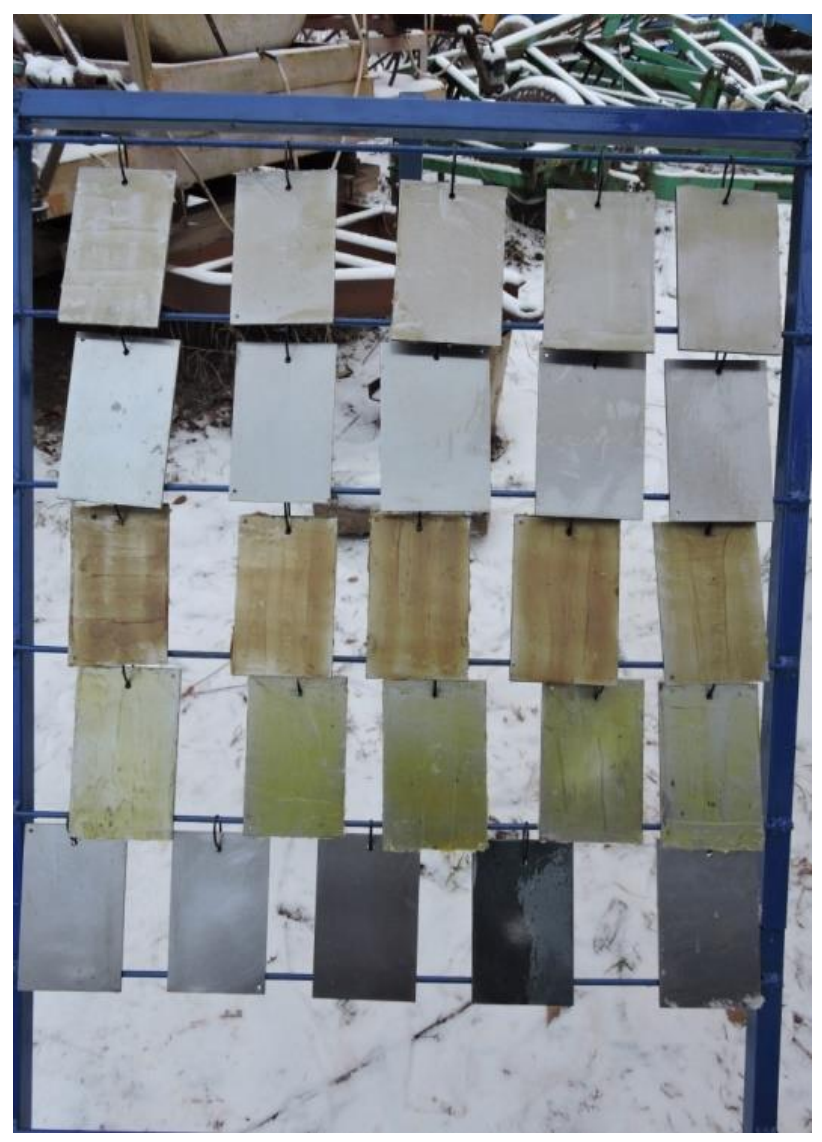

Fig. 1. Corrosion stand with samples

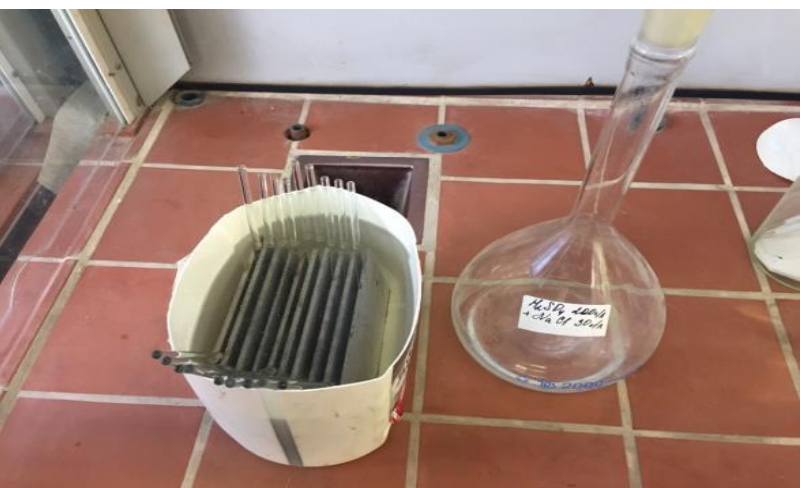

Fig. 2. Etching of samples

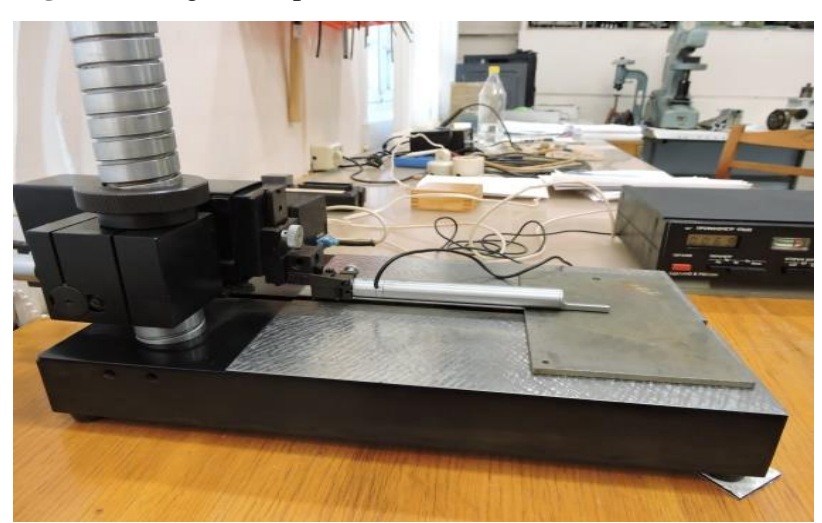

\section{Results}

The following parameters were important for assessing the protective properties of the compositions: the area and the number of corrosion centers, changes in surface roughness, and metal loss. The results of measurements of the area of corrosion damage were obtained (Table 2 and Fig. 4).

Table 2. Corrosion surface area of samples, $\%$

\begin{tabular}{|c|c|c|c|c|c|}
\hline \multirow{2}{*}{ Composition } & \multicolumn{6}{|c|}{ Steel grade } \\
\cline { 2 - 6 } & $\mathrm{U} 8$ & $65 \mathrm{G}$ & 45 & $\mathrm{St} 3$ & $40 \mathrm{H}$ \\
\hline Movil & 9.72 & 12.64 & 16.17 & 23.13 & 6.74 \\
\hline K-17 & 82.67 & 87.7 & 78.15 & 96.84 & 90.65 \\
\hline Cannon Lard & - & 2.57 & 7.18 & 8.54 & - \\
\hline Litol 24 & 6.75 & - & 11.13 & 8.34 & 5.11 \\
\hline EKS-1 & 4.71 & 3.54 & - & - & 2.56 \\
\hline
\end{tabular}

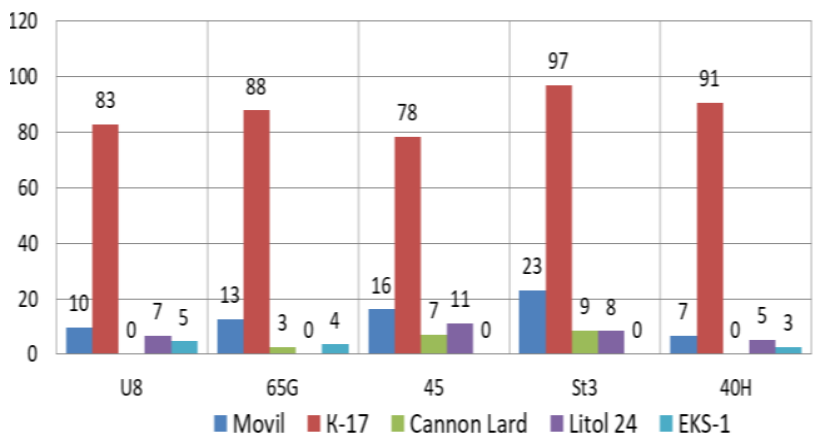

Fig. 4. Corrosion surface area of samples

Data analysis (Table 2) shows the following results:

- when using the experimental composition EKS-1 on samples of steel 45 and St3, the corrosion area is close to zero;

- when protecting specimens from U8 and $40 \mathrm{H}$ plates of steel, the composition was inferior only to cannon fat.

At the same time, when protecting a specimen made of $65 \mathrm{G}$ steel, EKS-1 showed good results comparable with the protective properties of greases and significantly exceeding the Movil and K-17 compounds. It should be noted that for a comprehensive assessment, it is necessary to take into account the number of corrosion centers that originate in local areas. Corrosion in local areas further provokes and enhances the development of surface corrosion. The results of measurements of the number of corrosion centers were obtained (Table 3 and Fig. 5).

Table 3. The number of foci of corrosion, pieces.

\begin{tabular}{|c|c|c|c|c|c|}
\hline \multirow{2}{*}{ Composition } & \multicolumn{5}{|c|}{ Steel grade } \\
\cline { 2 - 6 } & U8 & $65 \mathrm{G}$ & 45 & $\mathrm{St} 3$ & $40 \mathrm{H}$ \\
\hline Movil & 134 & 72 & 82 & 34 & 51 \\
\hline K-17 & 41 & 23 & 46 & - & - \\
\hline Cannon Lard & 18 & 24 & 42 & 28 & 24 \\
\hline Litol 24 & 22 & 16 & 14 & 31 & 37 \\
\hline EKS -1 & 47 & 35 & 42 & 12 & 51 \\
\hline
\end{tabular}

Fig. 3. Measurement of sample roughness 
The data obtained indicate that, despite the small corrosion area of the test samples treated with the composition EKS-1, the number of corrosion centers is quite large. Continuous corrosion begins to nucleate in the foci of occurrence but does not actively develop on the surface. Presumably, this can be explained by the "tears" of the protective film obtained on the metal surface due to atmospheric precipitation. However, the inhibitor continues to perform its function along the edges of the gap, and therefore no further development of corrosion on the metal surface occurs.

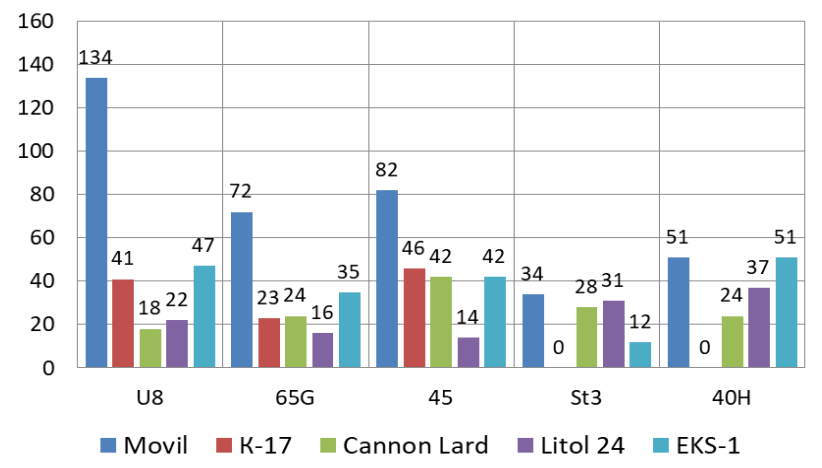

Fig. 5. The number of centers of corrosion on the surface of the samples

The value "zero" on samples of steel St3 and $40 \mathrm{H}$ coated with composition K-17 (Table 3 and Fig. 5) indicates that, due to continuous corrosion of the surface, the number of foci was not calculated. The degree of depth of metal damage can be indirectly estimated by the change in surface roughness (Table 4 and Fig. 6).

Table 4. Change in surface roughness of samples from the initial $\mathrm{Ra} 0.63$, microns

\begin{tabular}{|l|c|c|c|c|c|}
\hline \multirow{2}{*}{ Composition } & \multicolumn{5}{|c|}{ Steel grade } \\
\cline { 2 - 6 } & $\mathrm{U} 8$ & $65 \mathrm{G}$ & 45 & $\mathrm{St} 3$ & $40 \mathrm{H}$ \\
\hline Movil & 0.684 & 0.672 & 0.676 & 0.655 & 0.648 \\
\hline K-17 & 0.756 & 0.717 & 0.736 & 0.754 & 0.738 \\
\hline Cannon Lard & 0.684 & 0.676 & 0.680 & 0.661 & 0.658 \\
\hline Litol 24 & 0.658 & 0.648 & 0.651 & 0.642 & 0.644 \\
\hline EKS-1 & 0.646 & 0.651 & 0.639 & 0.635 & 0.641 \\
\hline
\end{tabular}

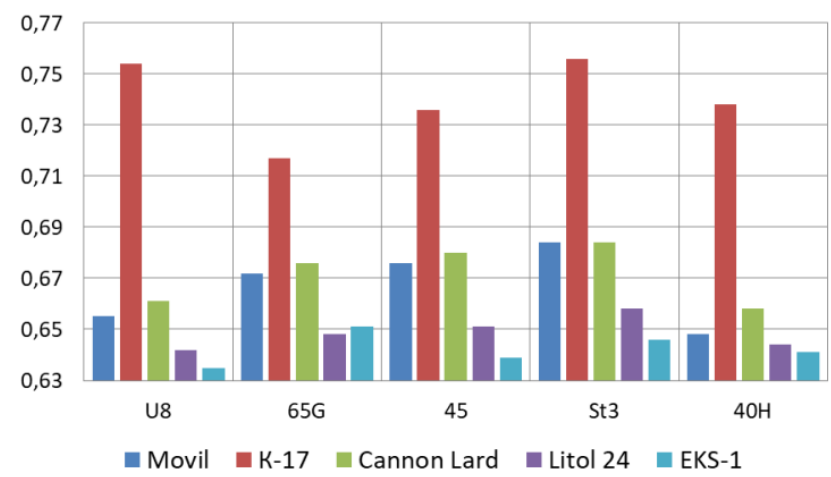

Fig. 6. Change in surface roughness of samples

As can be seen from the graph, the composition of EKS-1 in almost all steels surpasses the rest of the protective compositions. That is, despite the numerous formation of foci of corrosion, their depth is insignificant, which practically does not lead to a change in the surface roughness of the protected metal. The results of the change in metal losses during the year are obtained (Table 5 and Fig. 7).

The test results show that when applying St3 and 45 steel samples to the surface, metal losses amount to $2 \mathrm{~g} / \mathrm{m}^{2}$ per year, which exceeds the performance of all the compositions involved in the experiment. When protecting specimens from U8 and $40 \mathrm{H}$ plates of steel, the experimental composition is second only to cannon fat, and in the case of $65 \mathrm{G}$ steel only to Litol-24, which indicates its high efficiency.

Table 5. Loss of metal, $\mathrm{g} / \mathrm{m}^{2}$

\begin{tabular}{|l|c|c|c|c|c|}
\hline \multirow{2}{*}{} & \multicolumn{5}{|c|}{ Steel grade } \\
\cline { 2 - 6 } & $\mathrm{U} 8$ & $65 \mathrm{G}$ & 45 & $\mathrm{St} 3$ & $40 \mathrm{H}$ \\
\hline Movil & 14.7 & 12.7 & 18.7 & 27.3 & 12 \\
\hline K-17 & 18.7 & 15.3 & 22.7 & 36.7 & 35.3 \\
\hline Cannon Lard & 4.8 & 7.3 & 11 & 10.7 & 1.3 \\
\hline Litol 24 & 7.4 & 2.7 & 12 & 9.3 & 4.5 \\
\hline EKS-1 & 5.3 & 4.6 & 1.7 & 1.9 & 3.6 \\
\hline
\end{tabular}

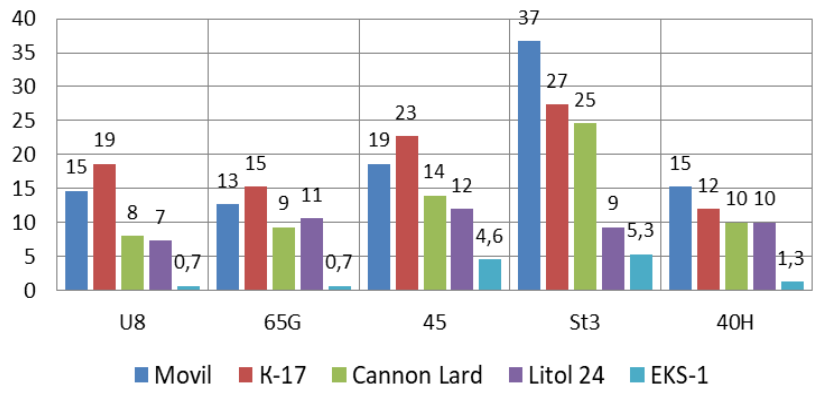

Fig. 7. Annual metal loss

\section{Conclusion}

The research results show that the use of the protective composition EKS-1, due to its manufacturability, significantly reduces the complexity of work during the conservation of agricultural machinery, as well as ensures the protection of metal products during both short-term and long-term storage.

\section{References}

1. E.B. Mironov, E.A. Lisunov, A.Yu. Gladtsyn, The process of formation and development of electrochemical corrosion of agricultural machinery, Agricult. Bull. of the Upper Volga, 4, 49-52 (2015) Retrieved from: http://ivgsha.ru/vestnik/ vestnik4_2015.pdf.

2. P. Zampieri, A. Curtarello, C. Pellegrino, E. Maiorana, Fatigue strength of corroded bolted connection, Fratturaed Integrità Strutturale, 12(43), 90-96 (2018) DOI: https://doi.org/10.3221/IGFESIS.43.06.

3. M.R.E. Tanjil, Y. Jeong, Z. Yin ey al., AngstromScale, Atomically Thin 2D Materials for Corrosion 
Mitigation and Passivation, Coatings, 9, 133 (2018) DOI: https://doi.org/10.3390/coatings9020133.

4. A.V. Shemyakin, M.B. Latyshenok, V.V. Terentyev, A way to increase the life of agricultural machinery, News of the South-West State Univer., 21(1), 50-56 (2017) Retrieved from: https://doi.org/10.21869/ 2223-1560-2017-21-1-50-56.

5. A.V. Machnev, I.A. Uspensky, M.Yu. Kostenko et al., Investigation of the safety of agricultural machinery under a heat shield with an adsorption dryer, Bull. of Ryazansky State Agrotechnolog. Univer. named after P.A. Kostychev, 1(37), 80-83 (2018) Retrieved from: http://vestnik.rgatu.ru/archive/2018_1.pdf.

6. A.V. Shemyakin, V.V. Terentyev, N.M. Morozova et al., Application of the cathodic tread protection method to reduce metal losses during storage of agricultural equipment, Bull. of the Ryazan State Agrotechnolog. Univer. P.A. Kostychev, 4(32), 9397 (2016) Retrieved from: http://vestnik.rgatu.ru/ archive/2016_4.pdf.

7. V.S. Pavlov, A.G. Smirnov, A.V. Ryazanov, Improvement of the anticorrosive properties of washing liquids, Bull. of the Chuvash State Agricult. Acad., 3(6), 103-107 (2018) Retrieved from: http://www.academy21.ru/nauka-i-innovacii/ vestnik-chuvashskoj-gsha-nauchnyj-zhurnal/

8. K.P. Andreev, V.V. Terentyev, A.V. Shemyakin, Storage of agricultural equipment: problems and solutions, Vestnik AIC Stavropol, 1(29), 10-13 (2018) Retrieved from: http://www.vapk26.ru/ journals/29.pdf.

9. V.V. Kozyrev, L.V. Kozyreva, V.V. Meshkov, M.A. Romanov, Improving the operability of flax harvesters with wear-resistant composite materials based on thermoplastics, Bull. of the NIIEI, 8(87), 34-47 (2018) Retrieved from: http://vestnik.ngiei. ru/?page_id=1650.

10. S.M. Gaidar, E.A. Petrovskaya, Improving the anticorrosive protection of machinery and equipment of the agro-industrial complex, in TLCA reports: Collection of articles, vol. 290, Part II, 225-227 (Publishing House of the RSAU-ICCA, Moscow, 2018) Retrieved from: https://www. timacad.ru/uploads/files/20180507/1525678641_tsh a-290_2.pdf.

11. E.A. Petrovskaya, S.M. Gaidar, Influence of anticorrosion treatment parameters on the corrosion resistance of products, in Mater. of the $X$ reg. sci. and pract. Conf. of students, graduate students and young scientists dedicated to memory of Associate Professor M.A. Anfinogenova, "State and innovations of technical service of machinery and equipment," (12-13 November 2018) 210-213 (Novosibirsk state agrarian university, Engineer institute, Novosibirsk, 2018) Retrieved from: http://www.mechfac.ru/files/lks/konf_nirm/ Condition\%20and\%20innovations\%20-techn. service_materials $\% 20 X \% 20$ conf.pdf.
12. E.A. Petrovskaya, S.M. Gaidar, Protection of equipment of livestock farms from corrosion, in Mater. of the X reg. sci. and pract. Conf. of students, graduate students and young scientists, dedicated to the memory of associate professor M.A. Anfinogenov, "State and innovations of the technical service of machinery and equipment" (12-13 November 2018) 214-217 (Novosibirsk state agrarian university, Engineer institute, Novosibirsk, 2018) Retrieved from: http://www.mechfac.ru/files/lks/ konf_nirm/Condition\%20and\%-20innovations\% 20techn.service_material\%20X\%20conf.pdf.

13. F.Zh.T. Taha, Improvement of equipment and technology for preserving agricultural machinery with inhibited bitumen compositions, $\mathrm{PhD}$ dissertation (Tambov, 2017) Retrieved from: http://mgau.ru/upload/iblock/449/449b59c4c2ca9b6 74e81ee8b32162803.pdf.

14. A.M. Gubasheva, Development of technology for the conservation of fertilizer spreaders with the justification of the parameters of the unit for applying protective compounds, $\mathrm{PhD}$ dissertation (Tambov, 2018) Retrieved from: http://mgau.ru/upload/iblock/f95/f95884730fbc5f7c dd015b632957d67d.pdf.

15. L.G. Knyazev, A.I. Petrashev, V.V. Klepikov et al., Fuel oil compositions for protecting agricultural machinery from atmospheric corrosion, Sci. in central Russ., 4(34), 65-73 (2018) Retrieved from: http://vniitin.ru/wp-content/uploads/2019/02/\%E2\% 84\%96-4-2018.pdf.

16. E.B. Mironov, V.V. Kosolapov, E.M. Tarukin, M.M. Maslov, Assessment of conservation materials for corrosion protection of the working bodies of agricultural machinery, Bull. of the NIIEU, A ser. of techn. Sci., 8(51), 45-57 (2015) Retrieved from: https://yadi.sk/i/USLogfgBmoECL

17. L.G. Knyazev, A.I. Petrashev, V.D. Prokhorenkov, V.V. Klepikov, On the issue of storage efficiency of agricultural machinery, Sci. in central Russ., 6(30), 37-49 (2017) Retrieved from: https://vniitin.ru/wpcontent/uploads/2018/03/№6-2017.pdf.

18. V.I. Vigdorovich, L.E. Tsygankova, L.G. Knyazeva et al., Study of the possibility of evaluating the protective effects of volatile inhibitors electrochemical polarization using copper and IFKHAN-114 as an example, Bull. of the Tambov State Techn. Univer., 24(3), 482-491 (2018) DOI: 10.17277 / vestnik.2018.03.pp.482-491.

19. V.I. Vinogradov, L.G. Knyazev, A.V. Dorokhov, Protection against corrosion in the atmosphere of livestock buildings, Sci. in central Russia, 6(36), 6777 (2018) Retrieved from: http://vniitin.ru/wpcontent/uploads/2019/02/\%E2\%84\%96-6-2018.pdf.

20. N.O. Eddy, P.O. Ameh, N.B. Essien, Experimental and computational chemistry studies on the inhibition of aluminum and mild steel in $0.1 \mathrm{M} \mathrm{HCl}$ by 3-nitrobenzoic acid, J. of Taibah Univer. for Sci., 
12(5), 545-556 (2018) DOI: $10.1080 \quad /$ 16583655.2018 .1500514 .

21. A.M. Samsudin, A.S. Pamungkas, R.E. Nugraheni, Corrosion Inhibitor of Carbon Steel from Onion Peel Extract, MATEC Web of Conf., 156, 03050 (2018) DOI: https://doi.org/10.1051/matecconf/ 201815603050.

22. R.M. Dakhil, T.S. Gaaz, A.A. Al-Amiery, A.A.H. Kadhum, Inhibitive impacts extract of Citrus aurantium leaves of carbon steel in corrosive media, Green Chemistry Letters and Reviews, 11(4), 559-566 (2018) DOI: 10.1080 / 17518253.2018 .1547796$.

23. Z. Zulfalina, N. Nadia, E. Yufita, Effect of Ceremai Leaf Extract (Phyllanthusacidus (L) Skeels) as Inhibitor Material on Corrosion Rate of Black Plate Steel (Base Plate) A36, J. of Aceh Phys. Society, 7(2), 98-101 (2018) Retrieved from: http:// jurnal.unsyiah.ac.id/JAcPS/article/view/8872/8823.

24. D.K. Verma, F. Khan, I. Bahadur et al., Inhibition performance of Glycine max, Cuscutareflexa and Spirogyra extracts for mild steel dissolution in acidic medium: Density functional theory and experimental studies, Results in Phys., 10, 665-674 (2018) DOI: https://doi.org/10.1016/j.rinp.2018. 06.003 .

25. E.M.S. Azzam, H.M. Abd El-Salam, R.A. Mohamed et al., Control the corrosion of mild steel using synthesized polymers based on polyacrylamide, Egyptian J. of Petrol., 27(4), 897-910 (2018) DOI: https://doi.org/10.1016/j.ejpe.2018.01.006.

26. J. Guo, S. Yuan, W. Jiang et al., Polymers for Combating Biocorrosion, Frontiers in Mater, 5, 10
(2018) DOI: https://doi.org/10.3389/fmats.2018. 00010.

27. O. Dagdag,, A.El. Harfi,, A. Essamri et al., Phosphorous-based epoxy resin composition as an effective anticorrosive coating for steel, Int. J. of Industr. Chem., 9(3), 231-240 (2018) DOI: https://doi.org/10.1007/s40090-018-0152-5.

28. C. Zhang, X. Dai, Y. Wang et al., Preparation and Corrosion Resistance of ETEO Modified Graphene Oxide, Epoxy Resin Coating, Coatings, 9, 46 (2019) DOI: 10.3390 / coatings9010046.

29. C. Zea, J. Alcantara, R. Barranco-Garcia et al., Synthesis and Characterization of Hollow Mesoporous Silica Nanoparticles for Smart Corrosion Protection, Nanomater., 8(7), 487 (2018) DOI: $10.3390 /$ nano8070478.

30. A.V. Pydrin, Development of technology for the conservation of agricultural machinery on the example of an internal combustion engine, $\mathrm{PhD}$ dissertation (Moscow, 2017) Retrieved from: http://www.old.timacad.ru/catalog/disser/kd/pudrin/ kd_pudrin.pdf.

31. T.M. Rakova, A.A. Kozlova, N.I. Nefedov, A.B. Laptev, Investigation of the effect of organic and inorganic corrosion inhibitors on the corrosion cracking of high-strength steels, Transact. of VIAM, 6(54), 102-110 (2017) Retrieved from: https: //viam-works.ru/plugins/content/journal/uploads/ articles/pdf/1122.pdf.

32. A.E. Shlykov, E.M. Tarukin, A.A. Kalashov, Comparative analysis of corrosion inhibitors, Agricult. Sci. J., 8, 68-71 (2018) DOI: https://doi.org/10.28983/asj.v0i8. 